\title{
DATA SYNCHRONIZATION MODEL TO IMPROVE THE SUPERVISION OF LAND OWNERSHIP FOR CITIZENS TOWARDS THE INDONESIAN AGRARIAN REFORM AGENDA
}

\author{
AGUS SEKARMADJI ${ }^{1}$, SRI HAJATI ${ }^{2}$, OEMAR MOECHTHAR ${ }^{*}$, NORAIDA HARUN ${ }^{3}$, REGINE \\ WIRANATA ${ }^{4}$ \\ ${ }^{1}$ Department of Administrative Law, Faculty of Law, University of Airlangga, 60286 Surabaya, Indonesia. \\ ${ }^{2}$ Department of Jurisprudence, Faculty of Law, University of Airlangga, 60286 Surabaya, Indonesia. \\ oemar.m@fh.unair.ac.id* (Oemar Moechthar) \\ ${ }^{3}$ Faculty of Law and International Relations, Universiti Sultan Zainal Abidin (UniSZA), 21300 Terengganu, Malaysia. \\ ${ }^{4}$ Faculty of Law, University of Airlangga, 60286 Surabaya, Indonesia.
}

\begin{abstract}
The change of ownership and control of agricultural and non-agricultural land for all Indonesian people is a mandate of Article 7, 10 and 17 of Act Number 5 Year 1960 under the Indonesian Agrarian Reform. In practice, however, people can own property rights beyond the stipulated limit. The article aims to improve a fair distribution of land through the proposed model of supervision and property rights land tenure reforms. The data synchronization developed through an online system can be the tool to improve the supervision and management of land ownership and tenures.

The methods used are the statute approach, socio-legal approach, and case study approach. The statute approach analysed existing statutes regarding land and land rights in Indonesia, the result is further observed in practice through the socio-legal approach by observing the data and figures in local regions. The case study approach reviews past judgments in the matter to examine the consistency and sufficiency of prevailing laws and policy and the direction of its developments.

This study found that there is still an ineffective implementation of the law resulting in people having lands more than their limit. The proposed data synchronization model developed through an online system can solve this problem by harmonizing data in local regions with the existing data at the Civil Registry Office and the Tax Office.

This study provides an essential contribution to the existing literature of Indonesian Agrarian Reform as well as a guideline for policymakers.
\end{abstract}

Keywords: Land Law, Land Rights, Indonesian Agrarian Reform, Equalization of Land Ownership, Land Tenure.

Article Received: 18 October 2020, Revised: 3 November 2020, Accepted: 24 December 2020

\section{Introduction}

Land is valued as among one of the timeless and inheritable treasures, and such, it is considered as an investment for the future. This is especially because the existence of land itself is far more interminable than human life. Hence, land always gets special attention and handling from human beings. Human beings also put on more effort to ensure control of their land. This is certainly easy to understand because almost every aspect of a community's life cannot be separated from the need for land. To recognize the importance of the function of land, the government is left with no alternative except to improve the processing, regulation, and management of land as a source for wealth in accordance with the existing Government Regulation.

The explanatory memory of Act Number 5 in Year 1960 on the Basic Regulation of Agrarian Principles (hereinafter referred to as UUPA) mentioned that one of the purposes of UUPA is to put the legal certainty basis regarding land rights for all Indonesian people. UUPA mentioned that one of the Indonesian Agrarian Reform Program is the overhaul of ownership and control of agricultural land and non-agricultural for all Indonesian people. This program is a mandate of the provisions of articles 7, 10 and 17 of the UUPA, which contain regulations on the ownership of agricultural land and non-agricultural land for Indonesian citizens. 
For agricultural land, this provision on Agrarian Reform is stipulated in Act Number 56 Prp 1960 on Determination of Land Area of Agriculture which regulates the determination of maximum and minimum area of agricultural land as referred to in Article 17 of UUPA. Residential houses, as nonagricultural land, is especially stipulated by the Decree of the Minister of Agrarian Affairs/Head of the National Land Authority Number 6 of 1998 concerning the Granting of Land Ownership Rights for Residential Houses.

Possession of a home is among the primary human needs after food; hence, to ensure the ownership of a residence for Indonesian citizens there is a need to ensure the continuity of the land rights of the dwellings. The UUPA recognized land rights for the residents; the ownership rights, the building rights, and the use rights. Regarding the ownership rights, people are prohibited to own a piece of land with a size that is more than five fields entirely, covering maximum $5,000 \mathrm{M}^{2}$. This provision is set forth as an effort to ensure an equal and fair distribution of land among the citizens. In practice, however, people can own property rights beyond the stipulated limit. This is still occurring until the present time; there are still people who own lands that has exceeded the maximum limitation of the property rights.

The vast geographical nature of Indonesia combined with the lack of data harmonization in the bureaucratic system further encourage this practice due to inefficient supervision. The development of technology may resolve this problem with the data synchronization model through an online system. An online system would enable a single database that makes it easier to check the status of land ownership of the citizens. In this model, the government would be able to perform the duties to monitor and manage land ownership of the citizens more easily with an access of a single database.

\section{Literature Review}

\subsection{Natural Resources on Indonesian Constitution}

Indonesia adheres to the ideology of Pancasila, the five principles that are keystones in the foundation of the State. The fifth principle of Pancasila is social justice for all the people, which refers to the position of Indonesia as a welfare State (Wicaksono, 2018) This is reflected in the provision of Article 33 Paragraph (3) of Indonesian Constitution 1945 which stated: "Earth, Water and Natural Wealth contained therein, are controlled by the State and used for the greatest prosperity of the people". The provisions in both Pancasila and the 1945 Constitution imply that the State is not the owner of the land; a prevailing Domain principle adopted by the colonial government prior to the stipulation of the UUPA. The State controls, hereinafter known as "The Right to Control of the State". Article 33 Paragraph (3) of The Indonesian Constitution 1945 is further elaborated by the UUPA through its Articles. Article 2 paragraph (1) stated that "On the basis of the provisions of Article 33 Paragraph (3) of The Constitution of Republic Indonesia in year 1945 and the matters referred to in Article 1, earth, water, and space, including the natural resources contained therein at the highest level are controlled by the State, As an organization of all Indonesian people”. Article 2 Paragraph (1) of the UUPA indicates a stance that, to achieve the objectives of Article 33 Paragraph (3) of Indonesian Constitution 1945, that the Indonesian nation or State acts as the owner of the land (Parlindungan, 1994)

Further clarification is provided in Article 2 paragraph (2) UUPA on the right to control of the State. With such rights, the State is authorized to: (1) organize and administer the allocation, stocks, inventory and maintenance of the earth, water and dwellings; (2) to determine and regulate the legal relations between people and the earth, water and dwellings; (3) to determine and regulate the legal relations between people and legal acts concerning the earth, water and dwellings. Based on the authority that the State possess to control the State, the organization has the power to: (a) to grant civil rights, either to individuals or private legal entities, 
such as property rights, long lease rights, building rights and rights to use; (b) recognize a pre-existing public rights such as customary rights of indigenous peoples (Article 3 UUPA); (c) to grant new public law, e.g. the management rights that are granted to governmental agencies or State/regional companies; (d) to grant the rights to use (exclusively) are given indefinitely and granted throughout the years of their duties, such as the right to use foreign representatives (Parlindungan, 1994).

The right to control of the State following the provisions in the Constitution and the UUPA encouraged a stronger State intervention in safeguarding the distribution of natural resources, including but not limited to land (Agustina, 2018). This right was stipulated as means to prevent the mismanagement or unlawful exploitation of natural resources that could result in the violations of the basic rights of the citizens in the fulfilment of their needs. The citizen rights over land regulated in UUPA are the ownership rights, the building rights, and the use rights. There is a limitation to this right as people are prohibited to own a piece of land with a size that is more than five fields entirely, covering maximum 5,000 $\mathrm{M}^{2}$. This limitation is set forth to ensure equal and fair distribution of lands among the citizens. It is the duty of the State to implement this provision to achieve its initial objective (Budiartha, 2018).

\section{Analysis And Discussion}

\subsection{The Practice of Existing Regulations}

On December 15, 2004, the Constitutional Court issued the Constitutional Court Decision no. 001021-022/PUU-I/2003, in relation to the request for judicial review of Act No. 20 of 2002 concerning Electricity, which is considered contradictory to the Indonesian Constitution 1945. The description of the Constitutional Court decision on Judicial Review of Act Number 22 Year 2001, Act Number 20 Year 2002 and Act Number 7 Year 2004 in face of the Article 33 of the Indonesian Constitution 1945 show that the above-mentioned refer to the definition of "controlled by the State" which must be interpreted to include a broad sense of meaning of control by the state derived from the conception of the sovereignty of the Indonesian people over all sources of "earth, water, and natural resources contained therein", including the understanding of public ownership of a collective of people over the sources of wealth concerned. The people collectively are built upon by the Indonesian Constitution 1945, which mandates the State to establish policies (beleid) and enact governmental executive duties (bestuursdaad), enact the regulation and laws (regelendaad), enact management (beheersdaad), and enact supervision (toezichthoudensdaad) for the greatest prosperity of the people. The state's management (bestuursdaad) function is carried out by the government with their authority to issue and revoke the facility's permits, licentie and consessie. The regulatory function of the State (regelendaad) is conducted legislatively by the parliament with the government, and the regulation by the government. The management function (beheersdaad) is conducted through stakeholder mechanism and/or through direct involvement in the management of State-Owned Enterprises or State-Owned Legal Entities as institutional instruments, through which the state, in this case the government, utilizes its control over the resources to be used for the greatest prosperity of the people. Similarly, the State's oversight function (toezichthoudensdaad) is carried out by the State, c.q. Government, to supervise and overview so that the performance of state over the intended resources are made for the greatest prosperity of all people (Magnar, 2010). The Regulation of the Minister of Agrarian Affairs and Spatial Planning/ Head of National Land Authority Number 25 of 2015 on the Strategic Plan of the Ministry of Agrarian Affairs and Spatial Planning/National Land Authority mentioned that the Indonesian region covers an area of approximately 840 million ha, which consists of 191 million ha of land and 649 million ha of ocean. Around 124.19 million hectares (64.93\%) of the region are still in the form of forests such as dense forests, similar forests, and forest. The remaining area of 67.08 million hectares $(35.07 \%)$ has been cultivated for various activities. The amount of 
land in Indonesia does not match the number of populations; therefore, it is necessary to distribute land tenures in an equitable manner so as not to allow certain groups to exceed the maximum limit of land control.

This is in line with one of the Strategic Plan of the Ministry of Agrarian Affairs and the Spatial Planning/National Land Authority as stipulated in the Regulation of the Minister of Agriculture and Spatial Planning/Head of the National Land Authority Number 25 of 2015 on the Strategic Plan of the Ministry of Agriculture and Spatial Planning/the National Land Authority, which stems from uneven spreading of increased of population in the regions of Indonesia. In the future, the population spread will target urban areas. The raise of population in urban areas will lead to an increased need for urban land. Since there is a need for land in one hand, while on the other hand there is progressively limited supply of it, this may lead to an augmentation of land conversions, including those deriving from productive agricultural land. Therefore, one of the strategic targets of the Ministry of Agrarian Affairs and Spatial Planning/National Land Authority which were formulated in 2015-2019 states "to increase the welfare of society using just and sustainable agriculture".

Based on the Decree of the Minister of Agrarian Affairs/Head of the National Land Authority Number 6 of 1998 concerning the granting of the ownership rights of land for residential property, in relation to the property rights ownership in which a person shall not have more than 5 fields, of which in its entirety should not cover not more than 5,000 $\mathrm{M}^{2}$, the fact however is in practice a person can own a property beyond the prescribed limit. Unfortunately, there is as yet no laws or regulations that levy sanctions for people in control of property rights exceeding the specified limits.

To encounter such practice, the Ministry of Agrarian Affairs and Spatial Planning/Head of the National Land Authority of the Republic of Indonesia has put in place as means of supervision a sealed official letter of statement signed by the applicant, which states that "the acquisition of the requested property right shall have the ownership rights of a residence land of not more than 5 (five) areas covering a total area of not more than 5,000 (five thousand) $\mathrm{m}^{2}$. Should the statement be proven to be false then the applicant is willing to be prosecuted in Court in accordance with the provisions of the applicable law regarding the misuse of false information in a written formal application". However, to date, prosecution through the Court, in terms of land tenure, almost never happens. It can be said that the Statement made by the applicant regarding the transfer of rights to land through the sale and purchase, exchange, grant, inbreng or inheritance is only a mere formality, because there are still many people who are still in ownership of property rights exceeding 5 fields or more than $5,000 \mathrm{M}^{2}$ as mentioned in Statement.

\subsection{The Supervisory Function and Management of Land Ownership Through The Data Synchronization Model}

Based on the fact that additional functions of the States among that is related to the management of natural resources, including land; which in this case is implemented by the Ministry of Agrarian and Spatial Planning/Head of the National Land Authority of the Republic of Indonesia, the latter may conduct supervisory actions management of citizens who are among those who have excess ownership of the property rights land as regulated in the Decree of the Minister of Agrarian Affairs/Head of the National Land Authority Number 6 of 1998. The Ministry of Agrarian Affairs and Spatial/Head of the National Land Authority of the Republic of Indonesia based on the medebewind principle is able to supervise the ownership of the property rights land through the Regional Office of the National Land Authority and the Regency/Municipality Land Registry Office by accessing the website of the National Land Authority which is available at www.bpn.go.id. Advances in technology has been able to assist the task of the Ministry of Agrarian Affair and Spatial Planning/Head of the National Land Authority of the Republic of Indonesia in terms of supervision and management of 
ownership of property rights land for citizens. The online system has been widely applied by the Regency/Municipal Land Registry Office in improving land public services, including land transition services through trade, exchange, grant, inbreng and inheritance. Indeed, the use of technology in government activities are on the rise in Indonesia, not only in form of website and databases but even to the form of contracts (Agustin \& Kurniawan, 2017).

The regulation concerning the ability to own land (as long as it does not exceed the regulated limit of 5 field of property rights land with a maximum size of $5,000 \mathrm{M}^{2}$ ) is applicable in all the regions in Indonesia. Thus, this weakness has become an obstacle for the Regency/Municipal Land Office in monitoring the number of the field of land submitted by an applicant. For example, Mr. A filed a request for property rights in Surabaya municipal through the Land Registry Office and filled out a statement of ownership of property rights as stipulated in the Decree of the Minister of Agrarian Affairs/Head of National Land Authority Number 6 of 1998. However, the Land Registry Office of Surabaya Municipal is not necessarily aware that Mr. A in addition to owning a plot of land in Surabaya also has a plot of land outside the city of Surabaya. This case occurred despite the fact that Surabaya has two land offices, namely Land Office of Surabaya I or Land Office of West Surabaya City and Land Office of Surabaya City II or Land Office of East Surabaya (Winarsi, Hajati \& Moechthar, 2018).

This proves that there is a problem rooting in the lack of data harmonization among institutions, moreover there is a gap from the data obtained in the local government to the data in the central government or the National Land Authority. The more databases that the governments have, the more discrepancies will exist between one another. This discrepancy is the root cause of the inefficient supervision and management of land ownership. Therefore, it is necessary to synchronize the online data to know what field of land is owned by the land rights applicant. This data should relate to the Civil Registry Office and the Tax Office when an applicant is in the process of applying for such a transfer of rights. With this data synchronization model, it is expected that the ownership of property rights land that exceeds the limit as mandated in UUPA can be minimized.

Considering that the state has five functions related to natural resources, the state in this case must be firm in supervising the land tenure that exceeds the limits set by the law. Strict sanctions must be imposed by the state on citizens for the realization of an agrarian reform program that was enacted since 1960 ago. Equitable welfare is indeed not easy to be realized by the state, but seeing the many phenomena of Indonesian citizens living on riverbanks, under bridges, even found living in plumbing caused by limited land and also increasing land prices, make the country obliged to protect and protect citizens in order to obtain proper housing as stated in the International Covenant on Economic, Social and Cultural Rights and which Indonesia has ratified through Law No. 11 of 2005.

The limited land available, especially in big cities, makes the country have to strategize so that ownership of land, especially houses, can be realized. The extent of the land horizontally makes the development of residential settlements vertically, or in Indonesia known as flats or apartments or condominiums or strata titles. The construction of these flats is mandatory, especially in an effort to relocate non-residential land and move to another place. A real example in Indonesia is that the indigenous law community in Asmat, Papua Province, where residents at that time were accustomed to living in swamps prone to contracting the disease. At least 71 people died in 2018 due to cases of malnutrition and measles that occurred in the region. The local government in collaboration with the Ministry of Social Affairs of the Republic of Indonesia finally provides social settlement assistance, life insurance, the assistance of seeds, work equipment and household appliances. Related to these settlements were established in the locations of Seramit, Auban and Sorai, Papua Province. Funding given at that time reached Rp. 1,100,000,000.00 (three billion one 
hundred million rupiah). Besides that, the Ministry of Social Affairs carried out the Family Hope Program in Agats District which applied to 175 Family Heads.

It is different from what happened in Jakarta, which is the largest metropolitan city in Indonesia. Data obtained from the Central Statistics Agency of the Republic of Indonesia and Databoks, Kadata Indonesia, the population of the city of Jakarta in 2017 is 10,370,000 (ten million three hundred seventy million). This can be seen from the following graph:

\section{Figure 1. Total Pupulation in Jakarta (1961-2017)}

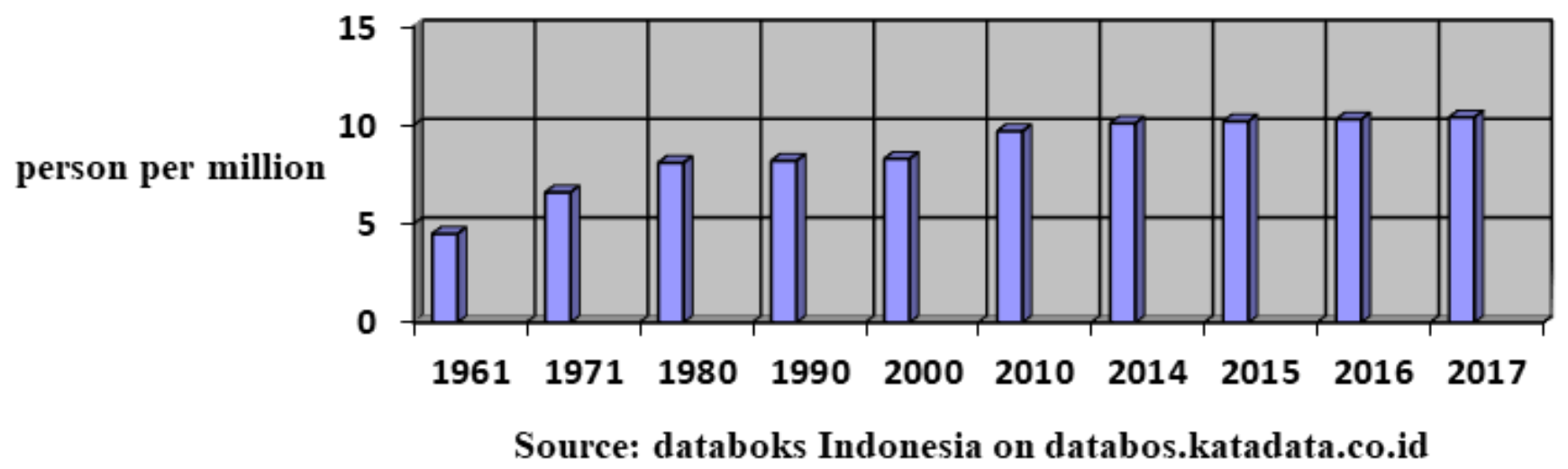

Over the past two years, the population in the capital city of Jakarta has increased by 269 people per day or 11 people per hour. This is predicted to increase every year. The government program in suppressing the number of births has not been sufficiently able to overcome the increasing population in Indonesia. This has implications for the roles and tasks for local governments and the central government to deal with this. Discussion to move the capital city from Jakarta to other cities is also being considered upon. Another effect that can be seen is an unhealthy residential area because very many Jakartans, especially Trans migrants who build non-permanent buildings in areas that are not made for housing in accordance with the Jakarta City Site Plan. Ultimately, the areas that are not intended as housing area became very densely occupied by Jakarta residents. The most common incident in these places are fire accident. This can be seen from fire case in Jakarta in 2018 which includes: fire cases in Petojo Selatan, Gambir, Central Jakarta; fire in residential areas in the
Tanah Tinggi area, Johar Baru, Central Jakarta; fire at Jalan Srengseng Sawah, South Jakarta; Fire case at Dempet Bridge Jalan Sumur Batu Raya, Sumur Batu, Kecamatan Kemayoran, Central Jakarta; Fires in densely populated settlements near Taman Kota Station, West Jakarta. This has become a major task of the government in terms of rearranging the city, especially areas of the population and slums into vertically built flats, thus the city of Jakarta can be more organized and green open areas can be realized by the government into habitable areas.

The condition in East Java Province is statically different. Referring to the data held by the Central Java Statistic Agency of East Java Province (Statistics Indonesia, East Java Province, 2017: 1314), specifically regarding "Housing Statistics and Settlement of East Java Province in 2017", data on the percentage of households according to the status of ownership was found. The data on the residential area in East Java in 2017 is as follows: 
Figure 2. Residential Area in East Java in 2017

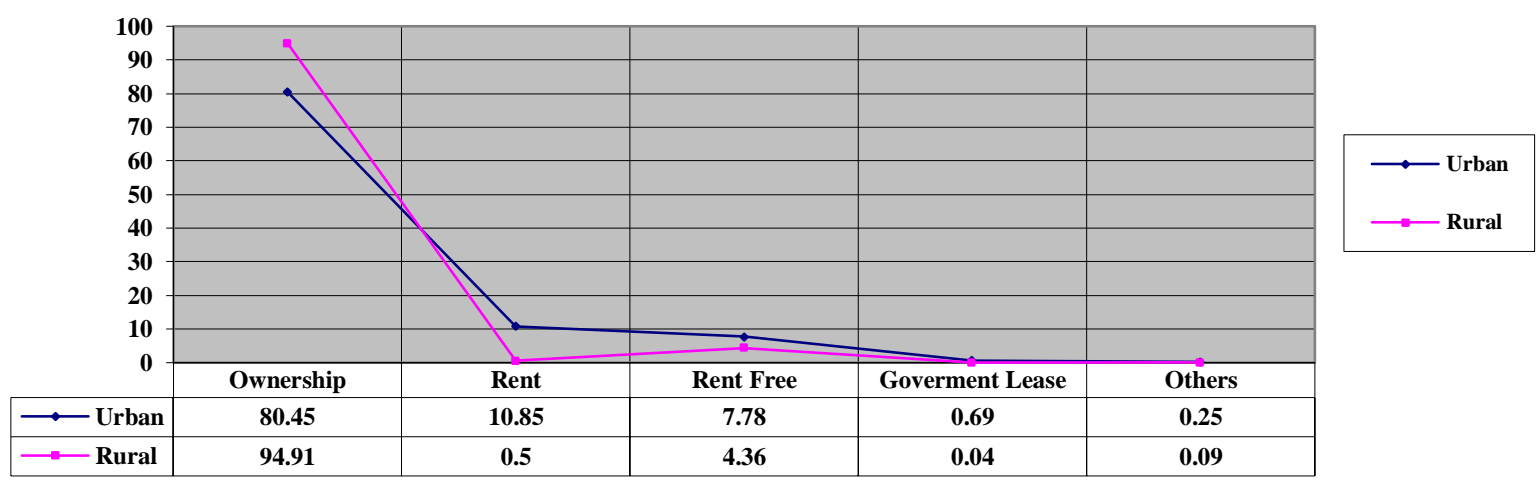

The problem of home ownership in urban areas remains a deep-rooted problem, where nearly twenty percent of households do not have their own homes. Whereas in rural areas, homes / residential buildings with self-owned status only amounted for five percent of households. One of the main factors that causes the high number of households in urban areas that do not have their own houses are mainly because of limited land in urban areas with a higher population density, so that the demand for housing needs will increase. This condition causes high prices for houses and land for settlements compared to rural areas.

When analyzed by district/city area, the biggest problem of housing backlog occurred in a row (from the lowest percentage of households that owned their own buildings/houses), namely in three areas of the city, that are: Surabaya (56.81\%), Madiun (58.49\%), and Malang (63.89\%). It is quite understandable that this condition occurs in these regions, mainly due to the rapid economy and the center of education in East Java, which increases the demand for land as a support for economic activities and educational support. While the three regencies, namely Pacitan (96.21\%), Bojonegoro and Tuban (96.08\%). The rapid economic activity in the city of Surabaya is also evident from the large number of households that live in homes or contracted or rented buildings. Where three out of ten households in Surabaya live in homes / residential buildings in the form of rent/contract. Malang City as an education center in East Java is in the second place, where 2-3 of ten households in Malang City live in rented houses.

Based on the explanation above, the circumstances that allow excessive land ownership is due to the distinctive needs of land in each specific region in Indonesia. Combined with the lack of data synchronization in the bureaucratic system that varies in regions, it results in the failure of supervision in the number of land ownership. Each District/Municipal Region have troubles to verify the current number of land ownerships by its Residents as there is simply no data. Each District/Municipal Region has their own database that is not well updated and connected with databases from the National Land Authority, the Central Government, or the other regions.

The data synchronization model through an online system can easily solve this problem by having a single database that stores the data of the citizens linked with the data in the Civil Registry Office and Tax Office. The website of the National Land Authority By having a single database, it is easier to monitor the ownership of the land by the citizens regardless of the regions that they live in. Moreover, if at any time there is any surplus of ownership property rights land by a person through the online system, the system will automatically reject the application and the ownership of the land exceeding the maximum limit may be redistributed to other citizens as is the intended objective of Agrarian Reform Indonesia. Thus, the objective of Article 33 Paragraph (3) of the Indonesian 
Constitution 1945 can be applied namely "Earth, Water and Natural Wealth contained therein, are controlled by the State and used for the greatest prosperity of the people".

\section{Conclusion}

The excessive land ownership by citizens due to the lack of supervision and management of land can be resolved through the data synchronization model with an online system. The model of supervision and management of tenure of property rights land as mentioned in the Decree of the Minister of Agrarian Affairs/Head of the National Land Authority Number 6 of 1998 which is the mandate of UUPA and Article 33 paragraph (3) of the Indonesian Constitution 1945 may be implemented through synchronization of applicant data and ownership land located on the District/Municipal Land Registry Office online system linked to existing data at the Civil Registry Office and the Tax Office. With this data synchronization model, it is expected that the ownership of land of property that exceeds the limit as mandated in UUPA can be minimized.

\section{REFERENCES}

[1] Agustin, E. \& Kurniawan, F (2017). Consumer Protection in Electronic Contracts: The Case of Indonesia. Journal of Nusantara Studies, 2(1), 159. https://doi.org/10.24200/jonus.vol2iss1pp1 59-169

[2] Agustina, E. (2018). The Social Function of Land Rights in Indonesia: The Basic Agrarian Law and Customary Rights by the State. Journal of Legal, Ethical and Regulatory Issues. https://www.abacademies.org/articles/thesocial-function-of-land-rights-inindonesia-the-basic-agrarian-law-andcustomary-rights-by-the-state-7573.html

[3] Budiartha, N. P. (2018). Restriction and incentives of investment in Indonesia: Considering the provisions of basic agrarian law and capital market law. European Research Studies Journal, 21(2),
178.

https://www.um.edu.mt/library/oar//handle /123456789/33407

[4] Magnar, K. (2010). Tafsir MK Atas Pasal 33 UUD 1945: (Studi Atas Putusan MK Mengenai Judicial Review UU No. 7/2004, UU No. 22/2001, dan UU No. 20/2002). Jurnal Konstitusi, 7(1). https://jurnalkonstitusi.mkri.id/index.php/j k/article/view/207

[5] Parlindungan, A. P. (1994). Komentar Atas Undang-Undang Pokok Agraria. Mandarmaju.

[6] Wicaksono, A. (2018). Reposition of local wisdom based on Pancasila on the function of the prosecution of attorney as a legal enforcement component in Indonesia. Asian Journal of Law and Jurisprudence, 1(1), 35 .

[7] Winarsi, S. Hajati, S., \& Moechthar, O (2018). Division of Land Services Based on Local Government Authority. Dinamika Hukum, $18(3)$, 260. http://dx.doi.org/10.20884/1.jdh.2018.18.3 .1892 